\title{
Resposta de cultivares de batata a níveis crescentes de NPK
}

\author{
Giovani Olegario da Silva ${ }^{1,4}$, Arione da Silva Pereira², Francine Elena Bail ${ }^{3}$, Rubens Ponijaleki ${ }^{4}$, \\ Agnaldo Donizete Ferreira de Carvalho ${ }^{5}$
}

10.1590/0034-737X201764050006

\begin{abstract}
RESUMO
A cultura da batata apresenta capacidade de resposta à adubação mais elevada que a de outras culturas. No entanto o uso exagerado de fertilizantes pode resultar no aumento do custo de produção e promover o desequilíbrio nutricional da planta, além da contaminação do ambiente. Desta forma, objetivou-se avaliar a resposta de cultivares de batata, melhorados e introduzidos, à aplicação de doses crescentes de NPK quanto à produtividade, ao peso específico e à coloração de fritura. O experimento foi realizado em Latossolo Vermelho Distrófico, em Canoinhas, SC, na primavera de 2014. Os tratamentos constaram de quatro doses de fertilizante NPK 04-14-08: 0, 3, $6 \mathrm{e} 9 \mathrm{t} \mathrm{ha}^{-1}$ aplicadas no plantio. O delineamento experimental foi em blocos casualizados, em arranjo de parcelas subdivididas, com três repetições, sendo as parcelas constituídas pelos cultivares e as subparcelas pelas doses de NPK. Após 120 dias do plantio, as variáveis foram avaliadas e analisadas estatisticamente (ANOVA e regressão polinomial). As doses crescentes de adubo NPK resultaram no aumento do número e do tamanho dos tubérculos, porém sem alteração do peso específico. Houve melhoria da coloração de fritura para todas cultivares, exceto para BRS Ana, com coloração mais clara. Os cultivares melhorados para as condições locais, BRS Ana e BRS F63 Camila, foram mais produtivos do que os cultivares introduzidos, Agata e Asterix, tanto com doses de adubo maiores, quanto menores, tendo sido o cultivar BRS F63 Camila o mais responsivo ao aumento da adubação. Dependendo do cultivar, a máxima viabilidade técnica estimada atingiu o valor máximo testado de 9,00 tha ${ }^{-1}$ de NPK na formulação 04-14-08, como no caso de BRS F63 Camila, porém a máxima viabilidade econômica variou de 5,77 a 9,00 t ha $^{-1}$.
\end{abstract}

Palavras-chave: Solanum tuberosum L.; adubação; BRS Ana; BRS F63 Camila.

\section{ABSTRACT}

\section{Response of potato cultivars to increasing levels of NPK}

Potato cultivation has the capacity to respond to higher fertilization levels than other crops. However, the exaggerated fertilization can result in increased production cost and promote nutritional imbalance of the plant, in addition to contamination of the environment. Thus, the aim of this work was to evaluate the response of potato cultivars, bred and introduced to increasing levels of NPK, in relation to yield, specific gravity, and fry color. The experiment was carried out in Haplustox soil, in Canoinhas - SC, Brazil, in the spring season of 2014. The treatments consisted of four doses of NPK 04-14-08 fertilizer applied at $0,3,6$, and $9 \mathrm{tha}^{-1}$. The experiment was conducted in a completely randomized block design $(R C B D)$ replicated three times. Treatments were arranged in a split-plot design with cultivars as main plots and NPK doses as sub-plots. At 120 days after planting, the characters evaluated were analyzed statistically by

Submetido em 17/04/2015 e aprovado em 13/07/2017

${ }^{1}$ Embrapa Hortaliças, Canoinhas, Santa Catarina, Brasil. giovani.olegario@embrapa.br

${ }^{2}$ Embrapa Clima Temperado, Pelotas, Rio Grande do Sul, Brasil. arione.pereira@embrapa.br

Faculdades Integradas do Vale do Iguaçu, Departamento de Agronomia, União da Vitória, Paraná, Brasil. francine.bail@hotmail.com

${ }^{4}$ Embrapa SPM, Canoinhas, Santa Catarina, Brasil. rubens.ponijaleki@embrapa.br

${ }^{5}$ Embrapa Hortaliças, Brasilia, Distrito Federal, Brasil. agnaldo.carvalho@embrapa.br

*Autor correspondente: giovani.olegario@embrapa.br

Rev. Ceres, Viçosa, v. 64, n.5, p. 492-499, set/out, 2017 
variance analysis and polynomial regression. It was found that with increasing doses of NPK fertilizer, there is an increase in the number and size of the tubers produced; however, it does not alter the specific gravity of tubers, but there was improvement in the fry color, except for BRS Ana that had lighter fry color. The cultivars developed for local conditions, BRS Ana and BRS F63 Camila, were more productive than the introduced cultivars, Agata and Asterix, both at higher and lower doses of fertilizer. BRS F63 Camila was the most responsive cultivar to increase of fertilizer. Depending on the cultivar, the maximum technical viability estimated was the maximum tested value of $9 \mathrm{t} \mathrm{ha}^{-1}$ of NPK in the formula 04-14-08, as in the case of BRS F63 Camila. However, the maximum economic viability estimated ranged from 5.77 to $9.00 \mathrm{tha}^{-1}$.

Key words: Solanum tuberosum L.; fertilization; BRS Ana; BRS F63 Camila.

\section{INTRODUÇÃO}

A maior parte dos cultivares de batata utilizados atualmente no Brasil foi desenvolvida na Europa. Entretanto, as condições brasileiras de clima e solo são diferentes daquele continente. $\mathrm{O}$ fotoperíodo é longo e a pressão de seleção para fatores bióticos e abióticos que afetam a cultura lá é baixa, diferente do Brasil, resultando em cultivares que, quando plantados em condições subtropicais e tropicais, apresentam períodos vegetativos (Rodrigues, 2006) e produtividades menores. Para conseguir maior produtividade é necessário o uso intensivo de fertilizantes, o que pode levar a menor sustentabilidade da cultura (Silva et al., 2013). Desta forma, a obtenção de cultivares adaptados às condições de cultivo nas diversas regiões produtoras brasileiras e com resistência às principais doenças é a alternativa viável para tornar a cultura produtiva e rentável ao agricultor (Gadum et al., 2003).

$\mathrm{Na}$ região sul do Brasil, a cultura da batata demanda alto investimento, podendo chegar a cerca de $\mathrm{R} \$ 20.000,00$ por hectare (insumos, operações mecânicas, mão de obra, custos administrativos, taxas de comercialização e beneficiamento e arrendamento) (Queiroz et al., 2013). Os fertilizantes, dependendo do preço e da época de cultivo, podem representar mais de $32 \%$ do custo de produção da cultura (Fernandes \& Soratto, 2013).

Trabalhos têm mostrado que a cultura da batata apresenta capacidade de resposta à adubação mais elevada que a de outras culturas. Esse desempenho pode ser atribuído ao elevado potencial de produção, ao ciclo curto e ao sistema radicular relativamente superficial dessa espécie, o que tem levado ao uso de grandes quantidades de fertilizantes por unidade de área (Queiroz et al., 2013). Muitas vezes, a adubação atinge níveis de $160 \mathrm{~kg}$ de N, $560 \mathrm{~kg}$ de $\mathrm{P}_{2} \mathrm{O}_{5}$ e $320 \mathrm{~kg}$ de $\mathrm{K}_{2} \mathrm{O}(\mathrm{KCl})$ em áreas de primeiro ano, e, 120,420 e $240 \mathrm{~kg} \mathrm{ha}^{-1}$, em áreas cultivadas anteriormente, o que equivale a 4.000 e $3.000 \mathrm{~kg} \mathrm{ha}^{-1}$ do adubo NPK 04-14-08, respectivamente (Mallmann et al., 2011).

As adubações são realizadas pelos produtores muitas vezes sem critério técnico (análise de solo), seguindo ape- nas recomendações genéricas baseadas em aspectos práticos para os mais variados tipos de solo, cultivares e finalidades da produção, sendo geralmente, muito maiores que as preconizadas pela pesquisa (Queiroz et al., 2013). O uso exagerado de fertilizantes pode resultar no aumento do custo de produção e promover o desequilíbrio nutricional da planta, além da contaminação do ambiente (Fontes et al., 1997).

Além disso, as tabelas de recomendação de adubação não consideram características específicas de cada cultivar. Segundo Fernandes et al. (2011), é importante fazer o manejo da adubação de acordo com o cultivar, principalmente N e K. Jenkins \& Hakoomat (1999) observaram diferenças entre os cultivares, sendo que aqueles com sistema radicular limitado apresentavam baixa capacidade de explorar os nutrientes do perfil do solo. O volume de raízes é particularmente importante para aqueles nutrientes que são relativamente imóveis no solo, como o fósforo (Nava et al., 2007).

Presume-se que cultivares desenvolvidos para condições de solos ácidos, como ocorre no Brasil, apresentem raízes mais profundas, sendo mais tolerantes à seca (Silva et al., 2013) e mais eficientes no aproveitamento dos nutrientes do solo.

Este trabalho teve como objetivo avaliar a produtividade, o peso específico e a coloração de fritura de cultivares de batata melhorados e apenas introduzidos em função de doses de adubação com NPK.

\section{MATERIAL E MÉTODOS}

O experimento foi realizado em Latossolo Vermelho distrófico (Embrapa, 2006), em Canoinhas, SC (26¹0' 38" S, 50²3’24" O, 839 m a.s.1.), na primavera de 2014.

O preparo do solo foi iniciado um mês antes do plantio envolvendo uma aração e uma gradagem, efetuando-se o sulcamento da área experimental por ocasião do plantio. A análise química do solo, antes da implantação do experimento, revelou os seguintes valores: matéria orgânica= 3,9\%; $\mathrm{pH}(\mathrm{SMP})=4,6 ; \mathrm{P}$ disponível $=56 \mathrm{mg} \mathrm{dm}^{-3} ; \mathrm{K}$ dispo- 
nível $=250 \mathrm{mg} \mathrm{dm}^{-3} ; \mathrm{Al}^{3+}=3,0 \mathrm{cmol}_{c} \mathrm{dm}^{-3} ; \mathrm{Ca}^{2+}=2,6 \mathrm{cmol}_{c}$ $\mathrm{dm}^{-3} ; \mathrm{Mg}^{2+}=0,9 \mathrm{cmol}_{\mathrm{c}} \mathrm{dm}^{-3} ; \mathrm{CTC}=22,6 \% ; \mathrm{SB}=4,1 \mathrm{cmol}_{\mathrm{c}}$ $\mathrm{dm}^{-3} \mathrm{e} \mathrm{V}=18 \%$.

Os tratamentos foram constituídos de quatro doses do formulado NPK 04-14-08 (0, 3, 6 e 9 t ha $\left.^{-1}\right)$, disponibilizadas em aplicação única em linha antes do plantio. $\mathrm{O}$ delineamento experimental foi em blocos ao acaso, com arranjo em parcelas subdivididas, com três repetições. Os cultivares BRS Ana e BRS F63 Camila (Pereira et al., 2015), indicadas para as condições locais de cultivo, e os desenvolvidos na Europa, mas amplamente cultivados no país, Agata e Asterix, foram alocados nas parcelas e, as doses de NPK, nas subparcelas. A subparcela foi composta por duas linhas de dez plantas, espaçadas de $0,80 \mathrm{~m}$ entre linhas e de $0,35 \mathrm{~m}$ entre plantas, respectivamente. O plantio dos tubérculos foi realizado em 26/08/14 e, após 15 dias, a amontoa foi realizada com enxada. Foram utilizadas sementes do tipo II, com dois meses de armazenamento em câmara fria $\left(3,5^{\circ} \mathrm{C}\right)$. Os tratos culturais e fitossanitários seguiram as recomendações da região (Pereira et al., 2010). $\mathrm{O}$ controle de plantas daninhas foi realizado mecanicamente, por ocasião da amontoa e, a aplicação de fungicidas. Feita preventivamente, especialmente mancozebe e oxicloreto de cobre. As plantas desenvolveram-se normalmente e as condições ambientais foram adequadas e não houve problemas com pragas ou doenças.

A colheita foi realizada 120 dias após o plantio e os tubérculos foram avaliados quanto às seguintes variáveis: número de tubérculos comerciais (diâmetro transversal $>45 \mathrm{~mm}$ ), não comerciais (diâmetro transversal $\leq 45$ $\mathrm{mm}$ ), e total, bem como a massa de tubérculos comerciais e não comerciais (em kg). A partir desses dados, calculouse, a massa total $(\mathrm{kg})$ e a média $(\mathrm{g})$ de tubérculos. Também foram calculados o peso específico, medido diretamente com hidrômetro da Snack Food Association (Silva et al., 2014a), e avaliada a cor de palitos fritos cortados longitudinalmente $(9,5 \mathrm{~mm})$, utilizando amostras de três tubérculos médios e sadios por parcela, fritados em gordura vegetal a temperatura inicial de $180^{\circ} \mathrm{C}$, por 2,5 minutos. Em seguida, atribuiu-se notas de 1 a $9(1=$ escuro, $9=$ claro $)$ (Silva et al., 2014a).

Os dados de produção de tubérculos foram transformados para $\mathrm{t} \mathrm{ha}^{-1} \mathrm{e}$ os de número de tubérculos transformados para ha-1/1000. Após verificação quanto à distribuição normal dos resíduos, por meio do teste de Lilliefors, procedeu-se a análise de variância com o programa Genes (Cruz, 2013) e a regressão polinomial por meio do procedimento PROC GLM do programa estatístico SAS (SAS Learning Edition, 2002).

A máxima eficiência técnica foi determinada para todas as variáveis componentes de produção e a econômica para a produtividade de tubérculos comerciais, considerandose os custos com a aplicação do NPK. Foram considerados no cálculo os valores de $R \$ 50,00$ por saca de $50 \mathrm{~kg}$ de NPK e $\mathrm{R} \$ 45,00$ por saca de $50 \mathrm{~kg}$ de batata comercializável. Os valores de máxima eficiência técnica foram calculados pela primeira derivada da equação: $\mathrm{y}=\mathrm{a}+\mathrm{bx}+\mathrm{cx}^{2}$, resultando na equação: $0=b+2 c x$. Para determinar a máxima eficiência econômica foi utilizada a mesma derivada da equação, multiplicando-se pelo preço do produto (pp) e subtraindo-se o preço do insumo (pi), resultando na equação: $0=p p(b+$ 2cx) - pi (Alvarez, 1991). Os valores máximos estimados foram limitados à dose máxima testada.

\section{RESULTADOS E DISCUSSÃO}

A análise de variância revelou diferenças significativas $(\mathrm{p}<0,05)$ entre os cultivares para todas as variáveis, com exceção da produtividade total de tubérculos, e não significativas entre as doses as doses do adubo NPK. Nesse ultimo caso foram detectadas apenas para as variáveis produtividade média de tubérculos e peso específico.

As produtividades obtidas neste trabalho estão próximas das verificadas em outros estudos, tendo sido constatadas produtividades total média de tubérculos de 26,93 t ha ${ }^{-1}$, enquanto para a produtividade comercial obteve-se $17,53 \mathrm{t} \mathrm{ha}^{-1} \mathrm{e} 92,56 \mathrm{~g}$ para a massa média de tubérculos. Silva et al. (2012), utilizando $2 \mathrm{t} \mathrm{ha}^{-1}$ de adubo formulado NPK 05-30-10, observaram para os cultivares Agata e Asterix, cultivados no mesmo município e na mesma época deste trabalho, produtividades total e comercial de tubérculos de 18,80 tha- ${ }^{-1}$ e 14,31 tha ${ }^{-1}$, respectivamente, e massa média de tubérculos de $77 \mathrm{~g}$. Em outro estudo, no mesmo ambiente, esses mesmos autores utilizaram $600 \mathrm{~kg}$ ha $^{-1}$ de nitrato de amônio, $700 \mathrm{~kg} \mathrm{ha}^{-1}$ de superfosfato simples e 233,80 $\mathrm{kg} \mathrm{ha}^{-1}$ de cloreto de potássio na linha de plantio. Silva et al. (2014b) verificaram para os cultivares BRS Ana e BRS Clara e para os cultivares Agata e Asterix, produtividades total e comercial de tubérculos médias de $26,07 \mathrm{t} \mathrm{ha}^{-1}$ e 11,58 $\mathrm{t} \mathrm{ha}^{-1}$, respectivamente, assim como massa média de tubérculos de $108 \mathrm{~g}$. Os cultivares melhorados (BRS Ana e BRS Clara) para as condições locais foram mais produtivos e apresentaram tubérculos maiores, com valores médios de 25,72 t ha ${ }^{-1}, 13,35$ tha $^{-1}$ e 122,54 $\mathrm{g}$, respectivamente para produtividades total e comercial de tubérculos e massa média de tubérculos, respectivamente. Os cultivares introduzidos (Agata e Asterix) apresentaram em média 22,33 tha ${ }^{-1}, 4,83 \mathrm{t} \mathrm{ha}^{-1}$ e $72,22 \mathrm{~g}$, respectivamente para os mesmos caracteres.

Em relação ao número dos tubérculos comerciais (> 45 $\mathrm{mm}$ de diâmetro), verificou-se um aumento com as doses crescentes de NPK para todos os cultivares. No tratamento de dose máxima ( $\left.9 \mathrm{t} \mathrm{ha}^{-1}\right)$, os maiores números de tubérculos comerciais foram obtidos com os cultivares BRS Ana (171.430 tubérculos ha ${ }^{-1}$ ) e BRS F63 Camila (151.740 tubérculos ha ${ }^{-1}$ ), comparativamente a Agata 
(132.060 tubérculos ha-1) e Asterix (128.890 tubérculos ha$\left.{ }^{1}\right)$. As diferenças dos números de tubérculos comerciais na dose 0 para a dose $9 \mathrm{t} \mathrm{ha}^{-1}$ foram maiores para o cultivar BRS F63 Camila (76.180 tubérculos ha ${ }^{-1}$ ), em comparação com BRS Ana (41.910 tubérculos ha-1), Agata (52.060 tubérculos ha-1) e Asterix (52.050 tubérculos ha- ${ }^{-1}$ ). O número total de tubérculos foi crescente para o cultivar BRS F63 Camila e máximo para as doses de 7,80 t ha-1 para BRS Ana, 7,09 t ha-1 para Agata e 8,67 t ha ${ }^{-1}$ para Asterix. O número de tubérculos não comerciais também cresceu até a dose máxima de adubação para o cultivar BRS F63 Camila, atingindo o máximo com as doses $5,66 \mathrm{t} \mathrm{ha}^{-1}$ para BRS Ana, 6,26 t ha ${ }^{-1}$ para Agata e 8,30 $\mathrm{t} \mathrm{ha}^{-1}$ para Asterix (Figura 1). Portanto, o número de tubérculos comerciais aumentou com as doses de NPK, porém as respostas foram diferentes entre os cultivares. Observou-se ainda o aumento do número de tubérculos total e de não comerciais em relação à dose zero. Queiroz et al. (2013) também verificaram aumento do número de tubérculos comerciais com a utilização de NPK na formulação 04-14-08 com o cultivar Agata, em Guarapuava, PR, sendo o número máximo observado com a dose de 4,6 t ha ${ }^{-1}$. Sangoi \& Kruze (1994) observaram aumento do número de tubérculos total e comerciais com as doses de NPK 05-20-10 para o cv. Baraka, em Lages, SC, e a máxima produtividade de tubérculos comerciais com 2,78 tha $^{-1}$ de fertilizante.
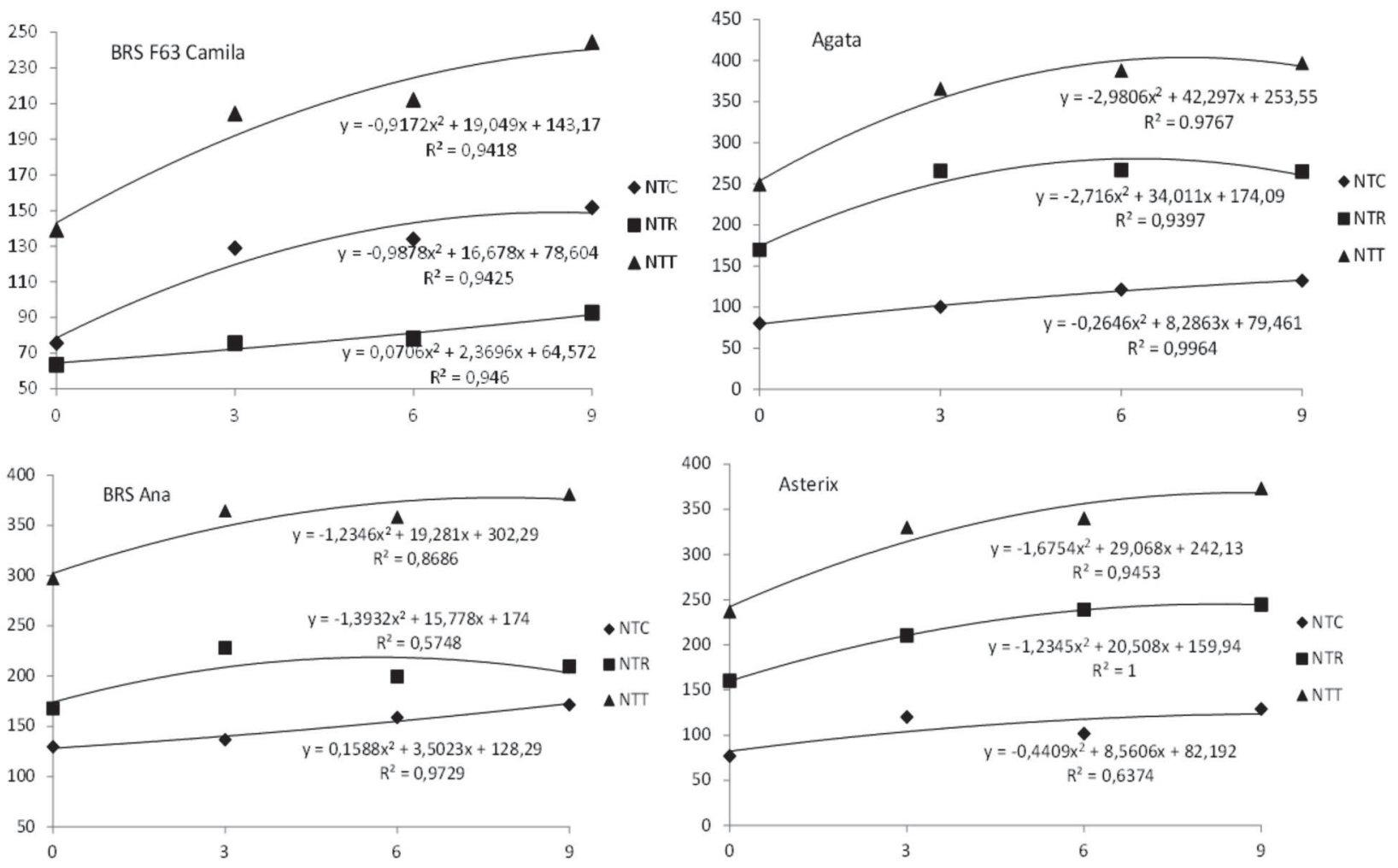

Figura 1: Número de tubérculos comerciais em $\mathrm{N}^{\circ}$ ha-1/1000 (NTC); número de tubérculos não comerciais em $\mathrm{N}^{\circ}$ ha ${ }^{-1} / 1000$ (NTR); número total de tubérculos em $\mathrm{N}^{\circ}$ ha-1/1000 (NTT) dos cultivares de batata BRS F63 Camila, BRS Ana, Agata e Asterix, em função da quantidade adubo NPK na formulação 04-14-08 aplicada por hectare.

Rev. Ceres, Viçosa, v. 64, n.5, p. 492-499, set/out, 2017 
dades de adubo, principalmente BRS Ana, indicando que são menos exigentes em adubação, mas responsivos com doses maiores de adubação, como ocorreu com BRS F63 Camila. Estas maiores produtividades, mesmo com doses menores de adubo, podem ser reflexo de melhor adaptação destas, pois presume-se que cultivares desenvolvidos sob condições de solos ácidos, como no Brasil, apresentem raízes mais profundas nessas condições, sendo mais tolerantes à seca (Silva et al., 2013) e mais eficientes no aproveitamento dos nutrientes do solo, especialmente os menos móveis no solo, como o P. Silva et al., (2014b) verificaram que, em comparação com os cultivares introduzidos Agata e Asterix, o cultivar BRS Ana, com ciclo vegetativo mais longo, apresentou maior produtividade de tubérculos, sendo o total de $34,19 \mathrm{tha}^{-1}$, a comercial de $22,72 \mathrm{t} \mathrm{ha}^{-1} \mathrm{e}$ a massa média de $160 \mathrm{~g}$. Pereira et al. (2010) verificaram que, para BRS Ana, as produtividades de tubérculos total e comercial foram de 35,70 tha-1 e 24,00 tha${ }^{1}$, respectivamente, com massa média de até $108 \mathrm{~g}$, enquanto, para a Agata foram de 25,36 tha $\mathrm{t}^{-1}, 15,23 \mathrm{t} \mathrm{ha}^{-1} \mathrm{e} 67$ $\mathrm{g}$, para Asterix, 32,40 tha ${ }^{-1}, 21,46 \mathrm{tha}^{-1}$ e $67 \mathrm{~g}$, respectivamente. Os resultados foram valores médios de várias safras e não foram comparados estatisticamente.

Não houve diferenças significativas entre as doses de adubação para a massa média dos tubérculos, porém houve diferenças entre os cultivares. O cultivar com maior massa média de tubérculos, na média das quatro doses testadas, foi BRS F63 Camila, com $130 \mathrm{~g}$, enquanto os demais cultivares apresentaram massas médias semelhantes, no caso: $90 \mathrm{~g}$ para BRS Ana, $70 \mathrm{~g}$ para Agata e $80 \mathrm{~g}$ para Asterix (Figura 3).

O peso específico, um atributo que correlaciona-se com a matéria seca dos tubérculos e reflete a crocância do produto, também não diferiu entre as doses de adubação avaliadas. O maior valor foi obtido para BRS Ana $(1,08)$, seguida de Asterix e BRS F63 Camila (1,07), sendo menores para Agata (1,06) (Figura 3). Fernandes \& Soratto (2013) avaliaram a absorção e o acúmulo de nutrientes do cultivar Agata (de baixa massa seca e destinada ao mercado de batata in natura), em comparação com cultivares destinados à fritura: Asterix, Mondial, Markies e Atlantic. Esses autores verificaram que Agata se destacou na produção de tubérculos frescos, enquanto Asterix e Mondial sobressaíram no acúmulo de massa seca. Pereira et al. (2010) verificaram que BRS Ana apresentou peso específico maior do que Agata e Asterix. Segundo Pauletti \& Menarin (2004), doses altas de K proporcionam diminuição do potencial osmótico e aumento da absorção de água, ocasionando a diluição dos teores de matéria seca dos tubérculos, efeito este não observado, neste estudo, até a dose máxima testada, que é equivalente a $720 \mathrm{~kg}$ de $\mathrm{P}_{2} \mathrm{O}_{5}$ ha ${ }^{1}$. Cardoso et al. (2007) também não observaram alteração da percentagem de massa seca com doses de $\mathrm{N}$ para o cultivar Vivaldi, em Mucugê, BA (entre 105 a $175 \mathrm{~kg} \mathrm{ha}^{-1}$
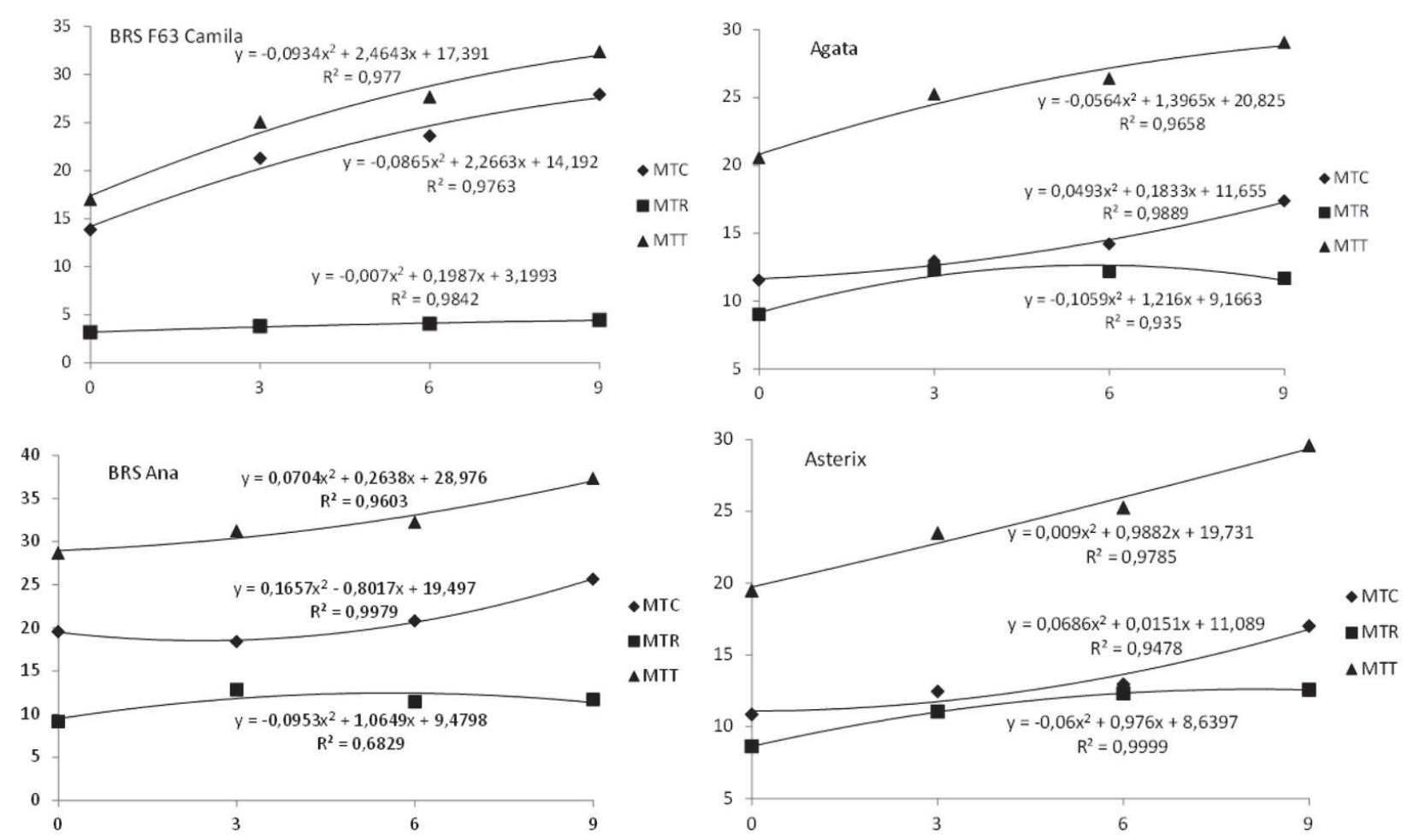

Figura 2: Produtividade de tubérculos comerciais em $\mathrm{t} \mathrm{ha}^{-1}$ (MTC); produtividade de tubérculos não comerciais em $\mathrm{t} \mathrm{ha}^{-1}$ (MTR) e produtividade total de tubérculos, em t ha ${ }^{-1}$ (MTT) dos cultivares de batata BRS F63 Camila, BRS Ana, Agata e Asterix, em função da quantidade adubo NPK na formulação 04-14-08 aplicada por hectare.

Rev. Ceres, Viçosa, v. 64, n.5, p. 492-499, set/out, 2017 
de $\mathrm{N}$ e de $\mathrm{K}$ (entre 210 e $350 \mathrm{~kg} \mathrm{ha}^{-1}$ de $_{2} \mathrm{O}$ ). O mesmo foi verificado por Braun et al. (2010), pois não observaram alterações dos teores de massa seca dos cultivares Agata, Asterix, Atlantic e Monalisa, em Viçosa, MG, com doses de $\mathrm{N}$ variando de 0 a $300 \mathrm{~kg} \mathrm{ha}^{-1}$.

Quanto à qualidade de fritura, verificou-se aumento dos escores de cor, ou seja, a coloração mais clara com o aumento das doses de adubo para os cultivares BRS F63 Camila, Agata e Asterix. Já para BRS Ana, que foi o que apresentou a melhor cor de fritura em todas as doses testadas, não foi possível visualizar melhoria da coloração com o aumento das doses de adubo aplicadas (Figura 3). Cardoso et al. (2007) não observaram alterações da quantidade de açúcares redutores com as variações das doses de $\mathrm{N}$ de 105 a $175 \mathrm{~kg} \mathrm{ha}^{-1}$ e de K, entre 210 e $350 \mathrm{~kg}$ $\mathrm{ha}^{-1}$ de $\mathrm{K}_{2} \mathrm{O}$. Esse é o principal componente responsável pelo escurecimento do produto frito, em batata. Oliveira et al. (2006) cultivaram o cultivar Asterix em substrato vegetal com fertirrigação, em Santa Maria, RS, verificando que a quantidade de $\mathrm{N}$ aplicada não afetou o teor de açúcares ou a coloração de fritura. As respostas diferenciais de cultivares, quanto a teores de açúcares redutores, a diferentes doses de nitrogênio, também foi relatada por Braun et al. (2010). Esses autores observaram incrementos nos teores em Agata e Monalisa, cultivares não adequados para fritura, o que não foi verificado em Asterix e Atlantic, esses destinados à fritura e que, sabidamente, apresentam melhor coloração de fritura.
Tais resultados não concordam com o observado para o cultivar BRS Ana neste estudo e que apresentou a coloração mais clara de fritura.

Para a produtividade de tubérculos comerciais, a máxima eficiência técnica foi estimada para dose equivalente à maior dose de NPK avaliada $\left(9 \mathrm{t} \mathrm{ha}^{-1}\right)$ foi verificada no caso do cultivar BRS F63 Camila. A máxima eficiência econômica, considerando-se o preço do produto a ser comercializado e o preço do adubo utilizado, foi estimada em 6,67 t ha ${ }^{-1}$, para BRS F63 Camila, em dose superior às observadas para Agata, 5,77 $\mathrm{t} \mathrm{ha}^{-1}$ para BRS Ana e 7,98 t ha $^{-1}$ para Asterix. De acordo com análise de solo (Comissão de Química e Fertilidade do Solo - CQFS-RS/SC, 1995), as quantidades de $\mathrm{P}$ e $\mathrm{K}$ a serem aplicadas no solo seriam apenas a reposição e, para N, $140 \mathrm{~kg} \mathrm{ha}^{-1}$. Para suprir a necessidade de $\mathrm{P}$ seriam necessários $715 \mathrm{~kg}$ de adubo NPK na formulação 04-14-08, para K $1.750 \mathrm{~kg} \mathrm{ha}^{-1}$ e para N $3.500 \mathrm{~kg} \mathrm{ha}^{-1}$.

Considerando-se como exemplo o cultivar BRS F63 Camila e utilizando-se a equação de regressão, estima-se que a produtividade de tubérculos comerciais, com uma adubação padrão de 3,5 tha ${ }^{-1}$ de NPK 04-14-08, seria de 21,06 t ha $^{-1}$, enquanto, com a máxima viabilidade econômica, 6,67 $\mathrm{t} \mathrm{ha}^{-1}$, ou seja, a produção seria $20,89 \%$ maior, equivalendo a 88 sacas, ou R\$3.960,00 por ha. Mallmann et al. (2011) verificaram que, para o cultivar Monalisa, em Pinhão, PR, um aumento de $6 \%$ da adubação com K resultou em um aumento de $28 \%$ da receita líquida da lavoura.
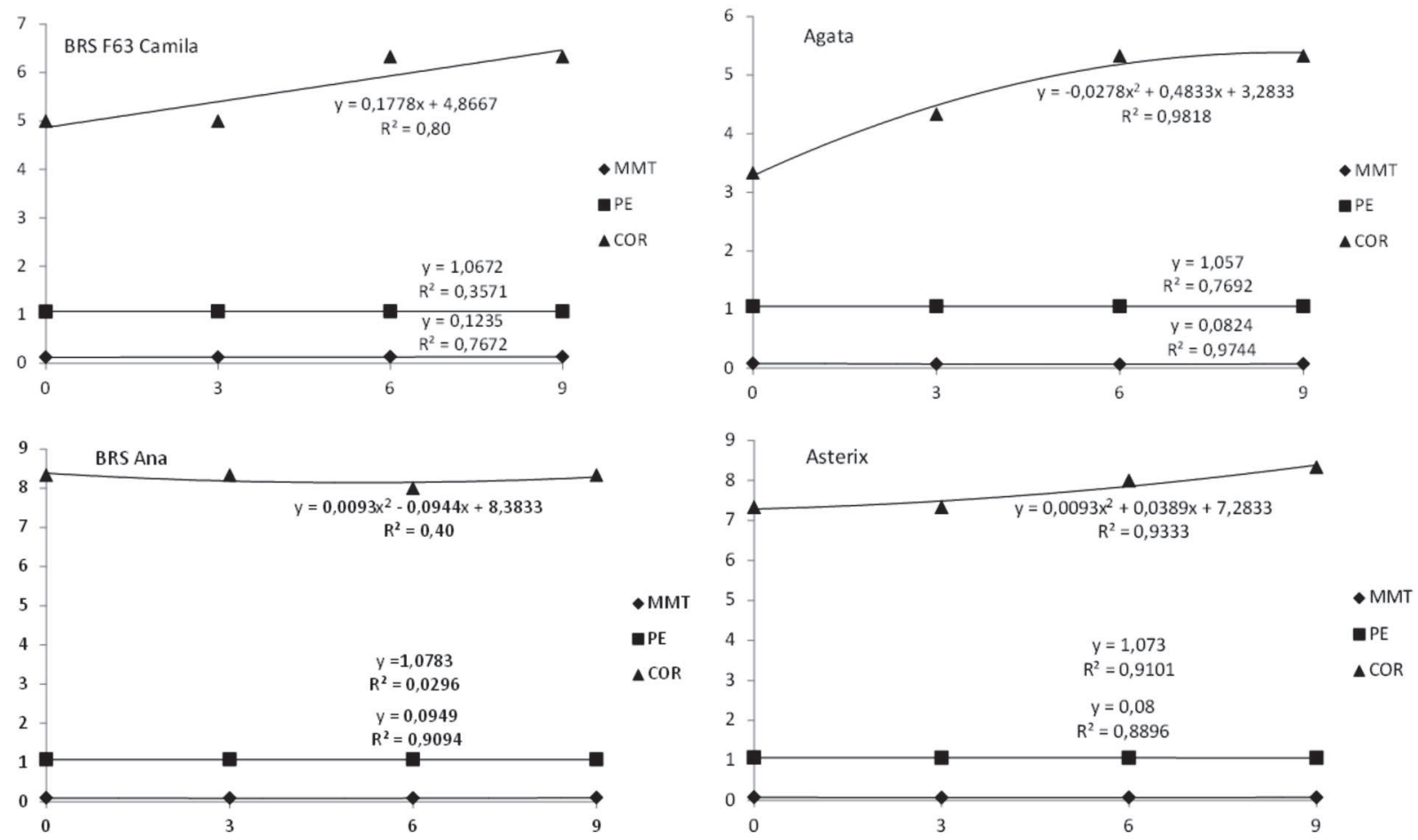

Figura 3: Massa média de tubérculos em g/1000 (MMT); peso específico (PE) e cor de fritura notas de 1 (escuro) a 9 (clara) (COR) dos cultivares de batata BRS F63 Camila, BRS Ana, Agata e Asterix, em função da quantidade adubo NPK na formulação 04-14-08 aplicada por hectare. 
Para altas produtividades, a extração de nutrientes é relativamente alta, estimando-se, para uma produção de 1 $\mathrm{t} \mathrm{ha}^{-1}$ de tubérculos, a extração de aproximadamente $8 \mathrm{~kg}$ de K, 5,3 kg de N e 1,2 kg de P. Além desses, têm-se valores para exportações aproximados de $4 \mathrm{~kg}$ de K, $3,3 \mathrm{~kg}$ de $\mathrm{N}$ e $1,0 \mathrm{~kg}$ de $\mathrm{P}$ (Nava et al. 2007). Queiroz et al. (2013), testando as doses 0, 2, 4 e $6 \mathrm{t} \mathrm{ha}^{-1}$ do adubo 04-14-08 com o cultivar Agata, em Guarapuava, PR, verificaram produtividades máximas de $41,1 \mathrm{t} \mathrm{ha}^{-1}$ de tubérculos comerciais com 4,2 t ha ${ }^{-1}$ de adubo, enquanto a máxima eficiência econômica foi atingida com a dose $3,5 \mathrm{t} \mathrm{ha}^{-1}$. Sangoi \& Kruze (1994), utilizando as doses 0, 1, 2, 3 e 4 t ha- ${ }^{-1}$ de NPK 05-20-10, em Lages, SC, com o cultivar Baraka, verificaram máxima eficiência técnica com 3,9 tha ${ }^{-1}$ de adubo. Mallmann et al. (2011) relataram que, para o cultivar Monalisa, em Pinhão, PR, a máxima receita líquida foi obtida com o incremento de $320 \mathrm{~kg}$ de $\mathrm{K}_{2} \mathrm{O}$ na dosagem tradicional de $3 \mathrm{t}$ ha $^{-1}$ de 04-14-08, e, para suprir toda a necessidade de $\mathrm{K}$ com esta formulação, seriam necessárias 7,0 $\mathrm{t} \mathrm{ha}^{-1}$ de adubo. Estes mesmos autores verificaram respostas ao $\mathrm{P}$ com doses acima de $800 \mathrm{~kg}$ de $\mathrm{P}_{2} \mathrm{O}_{5}$, mas a máxima eficiência econômica, para uma produtividade de $25,60 \mathrm{t} \mathrm{ha}^{-1} \mathrm{de}$ tubérculos comerciais, seria obtida com $918 \mathrm{~kg}$ de $\mathrm{P}_{2} \mathrm{O}_{5}$. Portanto, para suprir esta quantidade com a fórmula 04-14-08, seria necessário o equivalente a $6,55 \mathrm{t} \mathrm{ha}^{-1}$ de adubo, valores próximos aos obtidos neste trabalho. Da mesma forma, Nava et al. (2007), com o cultivar Monalisa em São Joaquim, SC, obtiveram resposta à adubação fosfatada para a produtividade total de tubérculos até as doses de 694 a 920 de $\mathrm{P}_{2} \mathrm{O}_{5}$, ou equivalente a 4,96 e 6,57 t ha-1 de adubo, se fosse suprida com a formulação 04-14-08.

A cultura da batata apresenta grande potencial de resposta à adubação em comparação a outras culturas. Esse desempenho pode ser atribuído ao elevado potencial de produção, ao ciclo curto e ao sistema radicular relativamente superficial dessa cultura (Queiroz et al., 2013). É prática comum, no País, apesar de diferenças regionais, a utilização de adubação padrão com o formulado 04-14-08, na dosagem de 3 a 4 t ha $^{-1}$ (Mallmann et al., 2011). No entanto, o uso de maiores quantidades de fertilizantes que aquelas exigidas pelas plantas pode resultar no aumento do custo de produção e promover o desequilíbrio nutricional da planta, além de causar contaminação do ambiente. Deve-se considerar também as flutuações anuais dos preços dos insumos e, principalmente, do produto que podem influenciar a viabilidade econômica, quando se utiliza adubações maiores.

\section{CONCLUSÕES}

Doses crescentes de adubo NPK resultam em aumento do número e do tamanho dos tubérculos produzidos, sem alteração do peso específico, porém com melhoria da coloração de fritura para todas cultivares avaliadas.
Para as condições em que se conduziu o experimento, os cultivares melhorados, BRS Ana e BRS F63 Camila, foram os mais produtivos do que os introduzidos, Agata e Asterix.

BRS F63 Camila é o mais responsivo ao aumento da adubação do que BRS Ana, Agata e Asterix.

Dependendo do cultivar, a máxima viabilidade técnica estimada foi correspondente à máxima dose testada, de 9 t ha ${ }^{-1}$ de NPK, na formulação 04-14-08, porém a máxima viabilidade econômica estimada varia de 5,77 a 9,00 tha-1.

\section{REFERÊNCIAS}

Alvarez VVH (1991) Avaliação da fertilidade do solo: Superfície de resposta - modelos aproximativos para expressar a relação fator resposta Viçosa, UFV. 75p.

Braun H, Fontes PCR, Finger FL, Busato C \& Cecon PR (2010) Carboidratos e matéria seca de tubérculos de cultivares de batata influenciados por doses de nitrogênio. Ciência e Agrotecnologia, 34:285-293.

Cardoso AD, Alvarenga MAR, Melo TL \& Viana AES (2007) Produtividade e qualidade de tubérculos de batata em função de doses e parcelamentos de nitrogênio e potássio. Ciência e Agrotecnologia, 31:1729-1736.

CQFS-RS/SC - Comissão de Química e Fertilidade do Solo (1995) Recomendações de adubação e calagem para os estados do Rio Grande do Sul e de Santa Catarina. $3^{\mathrm{a}}$ ed. Passo Fundo, SBCS. 224 p.

Cruz CD (2013) Genes; a software package for analysis in experimental statistics and quantitative genetics. Acta Scientiarum Agronomy, 35:271-276.

Embrapa - Empresa Brasileira de Pesquisa Agropecuária (2006) Centro Nacional de Pesquisa de Solos. Sistema Brasileiro de Classificação de Solos. $2^{a}$ ed. Brasília, Embrapa. 306p.

Fernandes AM, Soratto RP \& Beatrice LSR (2011) Extração e exportação de nutrientes em cultivares de batata: I macronutrientes. Revista Brasileira de Ciência do Solo, 35:20392056.

Fernandes AM \& Soratto RP (2013) Eficiência de utilização de nutrientes por cultivares de batata. Bioscience Journal, 29:91-100.

Fontes PCR, Rocha FAT \& Martinez HEP (1997) Produção de máxima eficiência econômica da batata em função de adubação fosfatada. Horticultura Brasileira, 15:104-107.

Gadum J, Pinto CABP \& Rios MCD (2003) Desempenho agronômico e reação de clones de batata (Solanum tuberosum L) ao PVY. Ciência e Agrotecnologia, 27:1484-1492.

Jenkins P D \& Hakoomat A (1999) Growth of potato cultivars in response to application of phosphate fertilizer. Annals of Applied Biology, 135:431-438.

Mallmann N, Lucchesi LAC \& Deschamps C (2011) Influência da adubação com NPK na produção comercial e rentabilidade da batata na região Centro-Oeste do Paraná. Pesquisa Aplicada \& Agrotecnologia, 4:67-74.

Nava G, Dechen AR \& Iuchi VL (2007) Produção de tubérculos de batata-semente em função das adubações nitrogenada, fosfatada e potássica. Horticultura Brasileira, 25:365-370.

Oliveira VR, Andriolo JL, Bisognin DA, Paula AL, Trevisan AP \& Antes RB (2006) Qualidade de processamento de tubérculos de batata produzidos sob diferentes disponibilidades de nitrogênio. Ciência Rural, 36:660-663. 
Pauletti V \& Menarim E (2004) Época da aplicação, fontes e doses de potássio na cultura da batata. Scientia Agrária, 5:1520 .

Pereira AS, Bertoncini O, Castro CM, Melo PE de, Medeiros CAB, Hirano E, Gomes CB, Treptow RO, Lopes CA, Nazareno NXR, Machado CMM, Buso JA, Oliveira RP \& Ueno B (2010) BRS Ana: cultivar de batata de duplo propósito. Horticultura Brasileira, 28:500-505.

Pereira A da S, Silva GO da, Bortoletto AC, Hirano E, Castro CM, Nazareno NRX, de, Souza Z da S. (2015) Catálogo de cultivares de batata. Embrapa: Documentos 373, 51p.

Queiroz LRM, Kawakami J, Muller MML, Oliari ICR, Umburanas RC \& Eschemback V (2013) Adubação NPK e tamanho da batata-semente no crescimento, produtividade e rentabilidade de plantas de batata. Horticultura Brasileira, 31:119-127.

Rodrigues GB (2006) Seleção divergente para duração do ciclo vegetativo em batata. Dissertação de mestrado. Universidade Federal de Lavras, Lavras. 55p.
Sangoi L \& Kruse ND (1994) Doses crescentes de nitrogênio, fósforo e potássio e características agronômicas da batata em dois níveis de pH. Pesquisa Agropecuária Brasileira, 29:13311343.

SAS Institute Inc. (2002) Getting Started with the SAS Learning Edition. Cary, SAS publishing. 86p.

Silva GO, Castro CM, Terres LR, Rohr A, Suinaga FA \& Pereira AS (2012) Desempenho agronômico de clones elite de batata. Horticultura Brasileira, 30:557-560.

Silva GO, Stoker G, Ponijaleki R \& Pereira AS (2013) Rendimento de tubérculos de três cultivares de batata sob condições de estiagem. Horticultura Brasileira, 31:216-219.

Silva GO, Pereira AS, Suinaga FA \& Ponijaleki R (2014a) Seleção de clones de batata para fritura com base em índices de seleção. Revista Ceres, 61:941-947.

Silva GO da, Bortoletto AC, Ponijaleki R, Mogor AF \& Pereira A da S (2014b) Desempenho de cultivares nacionais de batata para produtividade de tubérculos. Revista Ceres, 61:752-756. 